\author{
СОЦІАЛЬНО- \\ ЕКОНОМІЧНI \\ ДЕТЕРМІНАНТИ \\ РОЗВИТКУ \\ МІЖНАРОДНОГО \\ ТУРИЗМУ ТА \\ ТРУДОВОЇ МІГРАЦІї
}

ГОЛОВНЯ О. М.,
доктор економічних наук, доцент кафедри
менеджсменту зовнішньоекономічної діяльності,
готельно-ресторанної справи та туризму,
Вінницький національний аграрний університет
(м. Вінниця)

У статті розглядаються сучасні форми міжнародного руху людських ресурсів: міжнародного туризму та трудової міграції. Методи дослідження, використані у процесі написання статті, передбачали застосування загальнонаукових та емпіричних прийомів економічної науки, які трунтуються на системному підходi.

Визначено, щцо міжнародний туризм є формою міжнародного руху людських ресурсів, має масовий характер $і$ є однією з провідних високоприбуткових та найбільш динамічних галузей світового господарства. Досліджено основні туристичні тендениії на міжнародному туристичному ринку за традичійними географічними макрорегіонами. Проаналізовано найпривабливіші для відвідування туристичні напрямки за результатами популярного міжнародного туристичного порталу Lonely Planet. Протягом останнього десятиліття Активним учасником індустрії міжнародного туризму є Украӥна. У 2018 рочі найбільша кількість громадян з України виїхала до Польщі і складала майже 10 млн осіб.

Автор звертає увагу на одну із соціально-економічних проблем для національної безпеки: масштабну трудову та навчальну міграчію украӥнців до зарубіжних країн, яка іноді перетворюється на постійну (тобто призводить до зміни краӥни проживання). Набуття громадянами Украӥни права на вільне пересування Свропою співпало у часі зі структурними суспільно-економічними, освітніми, культурними та політичними трансформаціями, щуо супроводжувалися зростанням безробіття.

Досліджено, щуо впровадження безвізового режиму між Україною і СС та збільшення динаміки проиесів трудової міграції, формують тенденцію зменшення обсягів пропозииії праці на ринку в Украӥні, погіршення професійно-кваліфікаційного складу економічно активного населення в найбільш продуктивному віці.

Виявлено, що перетворення ринкових відносин на неринкові форми господарювання руйнує старі форми господарювання, вивільняючи при иьому численну робочу силу, яка не знаходить свого застосування в малопотужних індустріальних центрах Украйни та змушена шукати роботу на міжнародному ринку праці. Задоволення специфічних потреб мігрантів здійснює мультиплікативний вплив на економіку за рахунок витрат коштів на телефонні розмови з родиною, відвідування Батьківщини, відправлених грошових переказів.

Ключові слова: міжнародний рух людських ресурсів, міжнародний туризм, трудова міграція, суб'єкти туристичної діяльності, державне регулювання, економічний спад.

Табл.: 5. Літ.: 14.

\title{
SOCIO-ECONOMIC DETERMINANTS OF DEVELOPMENT INTERNATIONAL TOURISM AND LABOR MIGRATION
}



International Management, Hotel and Restaurant Business and Tourism, Vinnytsia National Agrarian University

\begin{abstract}
The article considers modern forms of the international movement of human resources: international tourism and labor migration. The research methods used in the process of writing the article involved the application of general scientific and empirical techniques of economics, based on a systematic approach.
\end{abstract}

It is determined that international tourism is a form of international movement of human resources, has a mass character and is one of the leading highly profitable and most dynamic sectors of the world economy. The main tourist tendencies in the international tourist market by traditional geographical macroregions are investigated. The most attractive tourist destinations to visit according to the results of the popular international tourist portal Lonely Planet are analyzed. Ukraine is an active participant in the international tourism industry. In 2018, the largest number of citizens from Ukraine left for Poland and amounted to almost 10 million people.

The author draws attention to one of the socio-economic problems for national security: large-scale labor and educational migration of Ukrainians to foreign countries, which sometimes becomes permanent (ie leads to a change of country of residence). The acquisition of the right to free movement by Ukrainian citizens coincided with profound structural socio-economic and political transformations, accompanied by rising unemployment.

It is studied that the introduction of visa-free regime between Ukraine and the EU and increasing the dynamics of labor migration processes form a tendency to reduce labor supply in the market in Ukraine, deteriorating professional qualifications of the economically active population at the most productive age.

It was found that the transformation of market relations non-market forms of management destroys the old forms of management, freeing a large labor force, which is not used in low-capacity industrial centers of Ukraine and forced to look for work in the international labor market. Meeting the specific needs of migrants has a multiplier effect on the economy by spending money on telephone conversations with family, visiting the homeland, sending remittances.

Keywords: international movement of human resources, international tourism, labor migration, subjects of tourist activity, state regulation, economic recession.

Tabl.: 5. Lit.: 14.

\title{
СОЦИАЛЬНО-ЭКОНОМИЧЕСКИЕ ДЕТЕРМИНАНТЫ РАЗВИТИЯ МЕЖДУНАРОДНОГО ТУРИЗМА И ТРУДОВОЙ МИГРАЦИИ
}

\author{
ГОЛОВНЯ Е.М. \\ доктор экономических наук, доцент кафедры менеджсмента \\ внешнеэкономической деятельности, \\ гостинично-ресторанного дела и туризма, \\ Винницкий нациннальный аграрный университет \\ (2. Винница)
}

В статье рассматриваются современные формы международного движения человеческих ресурсов: международного туризма и трудовой миграции. Методы исследования, использованные в процессе написания статьи, предусматривали применение 
общенаучных и эмпирических приемов экономической науки, основанные на системном подходе.

Определено, что международный туризм является формой международного движения человеческих ресурсов, имеет массовый характер и является одной из ведущих высокодоходных и наиболее динамичных отраслей мирового хозяйства. Исследованы основные туристические тендениии на международном туристическом рынке по традиционным географическим макрорегионами. Проанализированы наиболее привлекательные туристические направления для посещения по результатам популярного международного туристического портала Lonely Planet. Активным участником индустрии международного туризма является Украина. В 2018 году наибольшее количество граждан из Украины выехала в Польшу и составляла почти 10 млн. человек.

Автор обращзает внимание на одну из социиально-экономических проблем нацчиональной безопасности: масштабную трудовую и учебную миграџию украинцев в зарубежные страны, которая иногда превращуается в постоянную (то есть приводит к изменению страны проживания). Приобретения гражданами Украины права на свободное передвижение по Европе совпало во времени со структурными общественно-экономическими, образовательными, культурными и политическими трансформациями, сопровождавшиеся ростом безработицьь.

Доказано, что внедрение безвизового режима между Украиной и ЕС, увеличения динамики прочессов трудовой миграции формируют тенденцию уменьшения объемов предложения труда на рынке Украины, ухудшение профессионально-квалификачионного состава экономически активного населения в наиболее продуктивном возрасте.

Выявлено, что преобразования рыночных отношений нерыночные формы хозяйствования разрушает старые формы хозяйствования, высвобождая при этом многочисленную рабочую силу, которая не находит своего применения в маломощиных индустриальных иентрах Украины и вынуждена искать работу на международном рынке труда. Удовлетворения специифических потребностей мигрантов осуществляет мультипликативный влияние на экономику за счет расходования средств на телефонные переговоры с семьей, посещения родины, отправляя денежные переводы.

Ключевые слова: международное движение человеческих ресурсов, международный туризм, трудовая миграция, субъекты туристической деятельности, государственное регулирование, экономический спад.

Табл.: 5. Лит.: 14.

Постановка проблеми. Процеси глобалізації та економічної інтеграції часто передбачають не лише вільний рух товарів, капіталів та послуг, а й створення умов для єдиного ринку робочої сили. Тобто глобалізація та економічна інтеграція прискорюють міжнародний рух людських ресурсів. Основними формами міжнародного руху людських ресурсів є міграція та міжнародний туризм.

Підвищення мобільності людських ресурсів спричинює зміну характеру соціально-економічних відносин у сфері міжнародного туризму та трудової міграції, що вимагає розробки нових механізмів формування внутрішньої та зовнішньої політики держави. Державні та міжнародні інституції, які сприяють вільному руху товарів, послуг і капіталів, не завжди можуть успішно контролювати рух людських ресурсів, оскільки поєднати ліберальний режим для перших трьох факторів виробництва з обмеженнями для останнього досить важко. 
Від державної політики залежить, чи стане міжнародний рух людських ресурсів позитивним і стабілізуючим фактором, чи навпаки, буде чинником загострення соціально-економічних проблем держави.

Перша форма міжнародного руху людських ресурсів - міжнародний туризм, що формує світовий туристичний ринок, який є виявом глобальної економіки та одночасно залежний від всіх її елементів, механізмів та факторів.

Друга форма міжнародного руху людських ресурсів - трудова міграція. Для більшості країн із трансформаційною економікою, які переважно $є$ донорами робочої сили, трудова міграція має подвійний економічний ефект.

Аналіз останніх досліджень і публікацій. Міжнародний рух людських ресурсів як об'єкт досліджень у вітчизняному науковому просторі має тривалу історію. Науково-теоретичним та практичним аспектам міжнародного руху людських ресурсів у формах трудової міграції і міжнародного туризму присвячені наукові дослідження Джеджули О.М. [4], Кубай О.Г. [5], Малиновської О.А. [6], Садової У.Я. [8], Самойленко А.О. [9], Сардак С.Е. [10] та інших.

Мета дослідження. У дослідженнях, які присвячені міжнародному руху ресурсів, переважно розглядаються питання транзитно-професійних переміщень населення, що виникають внаслідок тимчасової територіальної мобільності людських ресурсів та віртуального міжнародного руху. Це викликано виробничими потребами їхньої професійної діяльності: державні службовці, які здійснюють офіційні візити до інших країн, працівники дипломатичних відомств і консульських служб, журналісти й інші особи. У той же час бракує досліджень, які стосуються трудової міграції, хоча трудова міграція та еміграція поступово стають провідними стратегіями життя багатьох українців.

Метою статті $\epsilon$ наукове обгрунтування теоретичних і практичних засад соціально-економічних ефектів трудової міграції та міжнародного туризму $\mathrm{i}$ їхнього впливу на національну економіку.

Виклад основного матеріалу дослідження. Міжнародна туристична індустрія є однією із рушійних сил, що виділяється 3-поміж інших елементів глобальної економіки, характеризується високою динамікою зростання та високим потенціалом розвитку, що впливає на формування найбільш глобальної економічної системи загалом. У 2019 році у світі було зареєстровано 1,5 мільярда міжнародних туристичних переміщень, що на 4\% більше порівняно 3 попереднім роком. Таким чином «зростання» туризму відбувається десятий рік поспіль [13].

Міжнародний туризм, який $\epsilon$ формою міжнародного руху людських ресурсів, має масовий характер і є однією з провідних високоприбуткових та найбільш динамічних галузей світового господарства. Специфічною рисою міжнародного туризму є те, що він поєднує у собі понад 50 суміжних сфер діяльності: культуру, мистецтво, освіту, спорт, готельне господарство, медицину, оздоровлення, торгівлю, харчування, транспорт, зв'язок, фінанси, побут, розваги, будівництво та інші. 
Глобалізація за допомогою індустрії туризму сприяє взаємодії народів, створюючи таким чином можливості для об'єднання населення різних країн відповідно до особистих потреб та інтересів.

У 2019 році зростання міжнародних туристичних потоків спостерігалося у всіх регіонах світу. Про це свідчать дані Всесвітньої туристичної організації $\mathrm{OOH}$ (UNWTO). Проте невизначеність навколо Brexit, геополітична напруженість і уповільнення темпів росту світової економіки все ж сповільнили зростання туризму у 2019 році порівняно з винятковими темпами 2017 року $(+7 \%)$ i 2018 року $(+6 \%)$. Найбільш швидкозростаючим регіоном для міжнародних туристичних прибуттів у 2019 році став Близький Схід $(+8 \%$, що майже вдвічі більше порівняно 3 минулим роком). А ось в АзіатськоТихоокеанському регіоні рівень зростання навпаки сповільнився, хоча, як і раніше, залишився вище середнього, а кількість міжнародних прибуттів зросла на 5\% [13].

Європа, де зростання також було повільнішим, ніж у попередні роки (+4\%), продовжує переважати за кількістю міжнародних прибуттів, прийнявши 743 мільйони міжнародних туристів за минулий рік (51\% світового ринку). Америка (+2\%) показала неоднозначну картину, оскільки багато острівних напрямків у Карибському басейні зміцнили своє відновлення після ураганів 2017 року, тоді як прибуття в Південну Америку знизилося почасти через тривалі соціальні та політичні потрясіння. Обмежені дані щодо Африки $(+4 \%)$ вказують на збереження високих результатів у Північній Африці (+9\%), тоді як у країнах Африки на південь від Сахари темпи зростання у 2019 році сповільнилися $(+1,5 \%)$.

Одночасно на тлі глобального економічного спаду витрати на туризм продовжували зростати. Так, Франція повідомила про найсильніше зростання витрат на міжнародний туризм серед десяти найбільших світових ринків виїзного туризму $(+11 \%)$, тоді як Сполучені Штати Америки $(+6 \%)$ були лідерами в абсолютному вимірі, чому сприяв сильний долар. Однак деякі великі ринки, що розвиваються, такі як Бразилія і Саудівська Аравія, повідомили про зниження витрат на туризм.

У першій половині 2019 року обсяг виїзних поїздок із Китаю, найбільшого «постачальника» туристів, збільшився на 14\%, хоча витрати скоротилися на 4\%. Водночас у UNWTO відзначають, що існуюча тенденція зростання міжнародних турпотоків вимагає відповідального управління туристичними потоками, розподіляючи їх в усьому світі в тих обсягах, у яких місцеві громади здатні це витримати [13].

При цьому, приблизно таке ж зростання турпотоку, як у 2019 році, прогнозувалося і на 2020 рік (від 3\% до 4\%), що підтверджує зростаючу роль туризму як провідного і сталого сектору економіки. Очікувалося, що масштабні спортивні події, включаючи Олімпійські ігри в Токіо, і культурні події, такі як ЕКСПО-2020 в Дубаї, позитивно вплинуть на сектор. 
На жаль, коронавірус спричинив найбільшу кризу в туристичній галузі за останні 20 років. За підрахунками фахівців, втрати туристичного потоку треба буде надолужувати наступні 5-7 років. Загалом очікуване у 2020 році падіння кількості міжнародних туристів призведе до зниження надходжень від міжнародного туризму на 300-450 млрд дол США [13].

Популярний міжнародний туристичний портал Lonely Planet опублікував список найкращих туристичних напрямків для відвідування. Кожен новий рейтинг традиційно помітно відрізняється від торішнього. Рейтинг Best in Travel від Lonely Planet складений на підставі думок професійних мандрівників у категоріях «Топ країн», «Топ міст», «Топ регіонів» і «Топ оптимальних напрямків» (табл. 1).

Варто відзначити, що до списку потрапили чимало відносно невідомих i екзотичних місць. Водночас жодна 340 туристичних дестинацій, включених у топи, не знаходиться в Україні. Першу сходинку в рейтингу найбільш популярних для подорожі країн зайняло буддійське королівство Бутан, розташоване в південній межі східних Гімалаїв між Індією і Китаєм.

Список найкращих туристичних напрямків за версісю міжнародного туристичного порталу Lonely Planet

\begin{tabular}{|c|c|c|c|}
\hline $\begin{array}{l}\text { № } \\
3 / \Pi\end{array}$ & Назва рейтингу & $\begin{array}{l}\text { Перше місце в } \\
\text { рейтингу }\end{array}$ & Основна характеристика туристичної дестинації \\
\hline 1. & $\begin{array}{l}\text { Топ-10 найкращих країн } \\
\text { для відвідування }\end{array}$ & $\begin{array}{l}\text { Королівство } \\
\text { Бутан }\end{array}$ & $\begin{array}{l}\text { Бутан - єдина у світі вуглецево-негативна країна (коли } \\
\text { вуглекислий газ із атмосфери поглинається, а не } \\
\text { викидається туди). Королівство збирається стати } \\
\text { першою у світі повністю органічною країною. }\end{array}$ \\
\hline 2. & $\begin{array}{l}\text { Топ-10 міст для } \\
\text { відвідування }\end{array}$ & $\begin{array}{l}\text { м. Зальцбург } \\
\text { (Австрія) }\end{array}$ & $\begin{array}{l}\text { Тут проходить музичний фестиваль академічної музики } \\
\text { і театрального мистецтва Salzburger Festspiele. }\end{array}$ \\
\hline 3. & $\begin{array}{l}\text { Топ-10 регіонів для } \\
\text { відвідування }\end{array}$ & $\begin{array}{l}\text { Центрально- } \\
\text { азіатський } \\
\text { шовковий шлях }\end{array}$ & $\begin{array}{l}\text { Маршрут проходить через Киргизстан, Таджикистан і } \\
\text { Узбекистан. }\end{array}$ \\
\hline 4. & $\begin{array}{l}\text { Топ-10 } \\
\text { оптимальних н напрямків } \\
\text { для відвідування }\end{array}$ & $\begin{array}{l}\text { Провінція Східна } \\
\text { Нуса-Тенгара } \\
\text { (Індонезія) }\end{array}$ & $\begin{array}{l}\text { Популярні природні пам'ятки: вулкан Келімуту з трьома } \\
\text { різнокольоровими озерами в кратерах, острів Комодо. }\end{array}$ \\
\hline
\end{tabular}

Джерело: складено автором за [13]

За опитуваннями туристичного порталу Lonely Planet, 68\% респондентів сказали, що стали більше дбати про екологічність своїх подорожей.

Це близько 200 одноденних турів, а також понад 130 турів до 65 країн. До одноденних турів включено, наприклад, пішохідну екскурсію до Сен-Жермен у Парижі, артпрогулянка до Лас-Вегаса або гастрономічний тур до Токіо. Серед більш тривалих турів - одинадцятиденний тур до північної Індії, а також восьмиденний тур до Італії поїздом.

Глобальна система бронювання Booking.com на підставі дослідженнь серед своїх користувачів прогнозує, що подорожі майбутнього будуть пов'язані 3 технологіями та почуттям відповідальності за навколишне середовище. Аби отримати подібні результати, було опитано 22 тис. мандрівників із 29 країн, а також досліджено більш ніж 180 млн верифікованих відгуків користувачів 
системи бронювання. Тренд майбутнього - за «повільними подорожами». 48\% опитаних Booking.com планували у 2020 році вдатись до більш спокійних видів транспорту, аби запобігти негативному впливу на навколишне середовище. «Повільні подорожі» можна здійснювати потягом, велосипедом, човном та, звичайно, пішки.

Активним учасником індустрії міжнародного туризму є Україна. Кількість громадян України, які виїжджали за кордон у 2018 році, становила 26437413 осіб (табл. 2). Найбільша кількість громадян із України виїхала до Польщі і склала у 2018 році майже 10 млн осіб. На другому місці знаходиться Російська Федерація, на третьому - Угорщина.

Таблиия 2

\section{Виїзд громадян України за кордон за країнами, до яких вони виїжджали у 2018 році, осіб}

\begin{tabular}{|c|c|c|c|c|}
\hline \multirow[t]{2}{*}{ Країна } & \multirow{2}{*}{$\begin{array}{c}\text { Кількість громадян } \\
\text { України, які } \\
\text { виїжджали за } \\
\text { кордон - усього }\end{array}$} & \multicolumn{3}{|c|}{ Із них - за метою поїздки } \\
\hline & & службова поїздка & $\begin{array}{c}\text { організований } \\
\text { туризм }\end{array}$ & приватна поїздка \\
\hline Усього & 26437413 & 97271 & 120887 & 26219255 \\
\hline у тому числі до країн & & & & \\
\hline Австрія & 115406 & 217 & 5174 & 110015 \\
\hline Білорусь & 1186466 & 42868 & 12656 & 1130942 \\
\hline Молдова & 1680353 & 1554 & 138 & 1678661 \\
\hline Польща & 9990978 & 1789 & 5059 & 9984130 \\
\hline Російська Федерація & 4376423 & 28177 & 1257 & 4346989 \\
\hline Румунія & 1045424 & 3475 & 5439 & 1036510 \\
\hline Туреччина & 1185051 & 7459 & 29495 & 1148097 \\
\hline Угорщина & 3118758 & - & - & 3118758 \\
\hline Словаччина & 854657 & - & - & 854657 \\
\hline Єгипет & 733597 & 375 & 14810 & 718412 \\
\hline Нідерланди & 114374 & - & - & 114374 \\
\hline Німеччина & 344150 & 195 & 4827 & 339128 \\
\hline Іспанія & 112982 & - & - & 112982 \\
\hline Італія & 173573 & 6 & - & 173567 \\
\hline
\end{tabular}

Джерело: складено автором за [3]

Сьогодні транскордонна мобільність населення України стрімко зростає передовсім за рахунок перетинів західного кордону. Залежно від причин, виокремлюють такі види міграції: релігійна, екологічна, культурно-оздоровча, освітня, політична, економічна.

Економічна міграція - переміщення населення між населеними пунктами в межах країни чи через міжнародні кордони 3 метою ведення економічної, інвестиційної, торговельної діяльності та спрямована на підвищення їхнього життєвого рівня. Основу економічної складає трудова міграція - територіальне переміщення економічно активного населення, пов'язане із зайнятістю чи пошуком роботи.

Однією із соціально-економічних проблем для національної безпеки є масштабна трудова та навчальна міграція до зарубіжних країн, яка іноді перетворюється на постійну (тобто призводить до зміни країни проживання). 
За професійно-кваліфікаційним рівнем трудову міграцію поділяють на: інтелектуальну, міграцію висококваліфікованих кадрів, некваліфікованих або низькокваліфікованих робітників [8, с. 11].

Виклики міграції набувають нових виявів в умовах безвізового режиму. Безвізовий режим зробив закордонні подорожі більш доступними, що звичайно сприяє активізації культурних обмінів та налагодженню ділових зв'язків між ЄС та Україною. Водночас в умовах безвізового режиму з СС активізується еміграція з України [1, с. 230].

За офіційною статистикою протягом 2015-2018 рр. кількість українських трудових мігрантів становила 1303,3 тис. осіб (табл. 3).

Таблиия 3

Трудові мігранти України за країнами перебування та категоріями мігрантів, протягом 2015-2018 рр., тис осіб

\begin{tabular}{|c|c|c|c|c|c|}
\hline & \multirow{3}{*}{$\begin{array}{c}\text { Кількість трудових мігрантів, } \\
\text { усього, тис. осіб }\end{array}$} & \multirow[b]{2}{*}{ Усього } & \multicolumn{3}{|c|}{ у тому числі за категоріями } \\
\hline \multirow{2}{*}{ 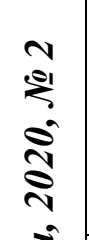 } & & & $\begin{array}{c}\text { трудові мігранти, які } \\
\text { повернулися до } \\
\text { України }\end{array}$ & $\begin{array}{l}\text { короткострокові } \\
\text { трудові мігранти }\end{array}$ & $\begin{array}{l}\text { працівники- } \\
\text { емігранти }\end{array}$ \\
\hline & & 1303,3 & 562,8 & 631,8 & 108,7 \\
\hline & & у тому чи & і за країнами перебува & ІНЯ, \% & \\
\hline & Польща & 38,9 & 36,2 & 45,2 & 16,0 \\
\hline & Російська Федерація & 26,3 & 35,4 & 20,9 & 9,8 \\
\hline & Італія & 11,3 & 8,5 & 8,1 & 44,1 \\
\hline & Чеська Республіка & 9,4 & 7,3 & 12,1 & 4,8 \\
\hline & США & 1,8 & 0,9 & 2,1 & 4,4 \\
\hline & Білорусь & 1,7 & 1,9 & 1,9 & - \\
\hline & Португалія & 1,6 & 2,4 & 0,2 & 5,2 \\
\hline & Угорщина & 1,3 & 0,6 & 2,0 & 0,6 \\
\hline & Ізраїль & 1,1 & 1,3 & 0,6 & 2,5 \\
\hline & Фінляндія & 1,0 & 0,3 & 1,9 & - \\
\hline & Німеччина & 0,8 & 0,2 & 0,9 & 2,9 \\
\hline & Інші країни & 4,8 & 5,0 & 4,1 & 9,7 \\
\hline
\end{tabular}

Джерело: складено автором за [3]

Таблиця 3 свідчить про найбільшу кількість трудових мігрантів з України до Польщі, що пояснюється різними причинами. 31 січня 2018 р. у Польщі було запроваджено нові правила, які дають змогу громадянам України працювати в Польщі дев'ять місяців протягом року. Відкритість кордонів Польщі для трудових мігрантів пов'язана 3 великою кількістю вакансій на польському ринку праці. За даними звіту польської компанії Personnel Service «Барометр трудової міграції», кожна п'ята компанія мала намір найближчим часом шукати працівників із України.

У 2018 р. Польща видала українцям 1,4 млн запрошень на роботу, при тому, що у 2010 р. таких запрошень було 180 тис. [11]. Реальні масштаби трудової міграції більші. Офіційна статистика не враховує довгострокових мігрантів, які виїхали всією сім'єю і на час аналізу не поверталися в Україну, а 
також маятникових мігрантів, які мають трудові відносини або ведуть домашнє господарство в Україні і періодично працюють за ії межами. За підрахунками експертів, Україна має 4 млн осіб трудових мігрантів, або $16 \%$ працездатного населення найбільш активної та продуктивної робочої сили [14].

Отримання можливості громадянами України вільного пересування країнами Свропи співпало у часі 3 глибокими структурними соціальноекономічними та політичними трансформаціями, що супроводжувалися зростанням безробіття та погіршенням майнового стану населення.

Віднесення низьких заробітних плат до конкурентних переваг деякими економістами у попередні десятиліття призвело до системної кризи ринку праці, що зумовило зменшення частки оплати праці у структурі ВВП. Відбулося згортання можливостей реалізації трудового потенціалу працюючого населення в Україні та збільшення залежності населення від доходів, зароблених за кордоном.

У найбільш вразливому становищі перебувають нелегальні мігранти, що ризикують зіткнутися не лише 3 порушенням своїх трудових прав, а й можуть бути обмануті роботодавцями. Крім того, у цій сфері сформувався тіньовий ринок. Некомерційні організації та приватні підприємці надають широкий спектр послуг для мігрантів в обмін на винагороду, встановлену на тіньовому ринку: таємне проникнення через кордон, трудові контракти між працедавцями та мігрантами, фальшиві документи і візи, фіктивний шлюб між мігрантами i законними резидентами чи громадянами країни призначення, надання кредиту та інші види допомоги у країні призначення [8, с. 18].

Результати аналізу соціологічних центрів демонструють суттєвий вплив житлової проблематики на мотиви виїзду за кордон у пошуках працевлаштування. Згідно з дослідженнями, проведеними Всеукраїнською асоціацією 3 міжнародного працевлаштування, серед основних причин, що мотивують людей працювати за кордоном, є неможливість в Україні заробити кошти для купівлі житла, а 31 \% українців використовують для вирішення житлових питань фінанси членів своїх родин, які працюють чи живуть за кордоном [2].

Вплив міграції на внутрішній ринок праці неоднозначний. За розрахунками демографів, за відсутності трудових міграцій рівень безробіття в Україні був би в 1,7 рази вищим, ніж фактичний. Водночас у регіонах масового відпливу мігрантів (Львівська, Закарпатська, Івано-Франківська області) уже нині спостерігається нестача медичних працівників, будівельників, зварювальників, водіїв, фахівців нафтовидобування. Збереження подібних проявів трудової міграції справлятиме негативний вплив на соціальноекономічну ситуацію в Україні.

В умовах зростання трудової міграції динамічно зростають і обсяги грошових переказів мігрантів на Батьківщину. Грошові перекази можуть здійснюватися офіційними (через відділення банків, міжнародні системи грошових переказів, поштові відділення) та неофіційними (шляхом передачі 
наявних грошей та інших матеріальних цінностей від одного суб'єкта іншому) каналами.

Таблиия 4

Трудові мігранти України за статтю, місцем проживання до виїзду за кордон та розміром середньомісячного заробітку протягом 2015-2018 рр.

\begin{tabular}{|c|c|c|c|c|c|c|c|}
\hline \multirow{2}{*}{ Показники } & \multirow{2}{*}{$\begin{array}{r}\text { Усього, } \\
\text { тис. осіб }\end{array}$} & \multicolumn{5}{|c|}{$\begin{array}{c}\text { у тому числі за середньомісячним } \\
\text { заробітком, дол. США, \% }\end{array}$} & \multirow{2}{*}{$\begin{array}{l}\text { Середньомісячний } \\
\text { заробіток одного } \\
\text { трудового мігранта, } \\
\text { дол. США }\end{array}$} \\
\hline & & до 250 & $\begin{array}{c}251- \\
500\end{array}$ & $\begin{array}{l}501- \\
1000\end{array}$ & $\begin{array}{l}1001- \\
2000\end{array}$ & $\begin{array}{l}\text { понад } \\
2000\end{array}$ & \\
\hline $\begin{array}{l}\text { Кількість трудових мігрантів, } \\
\text { які повідомили про розмір } \\
\text { середньомісячного заробітку, } \\
\text { усього }\end{array}$ & 1075,5 & 10,5 & 27,4 & 49,2 & 8,6 & 4,3 & 722 \\
\hline Жінки & 308,3 & 13,1 & 34,5 & 44,7 & 6,0 & 1,7 & 614 \\
\hline Чоловіки & 767,2 & 9,4 & 24,5 & 51,1 & 9,7 & 5,3 & 766 \\
\hline Міські поселення & 520,5 & 11,6 & 22,9 & 49,3 & 9,8 & 6,4 & 776 \\
\hline Сільська місцевість & 555,0 & 9,4 & 31,5 & 49,2 & 7,5 & 2,4 & 671 \\
\hline
\end{tabular}

$$
\text { Джерело: складено автором за [3] }
$$

За даними Національного банку України, грошові перекази в Україну з-за кордону з 2015 по 2019 рр. зросли з 6959 до 12017 млн дол. США (табл. 5).

Таблиия 5

Обсяги приватних грошових переказів в Україну за основними країнами за офіційними та неофіційними каналами надходження

\begin{tabular}{|c|c|c|c|c|c|c|}
\hline \multirow[t]{2}{*}{ Країна } & \multicolumn{2}{|c|}{2015 рік } & \multicolumn{2}{|c|}{2018 рік } & \multicolumn{2}{|c|}{2019 рік } \\
\hline & $\begin{array}{c}\text { млн. дол. } \\
\text { США }\end{array}$ & $\begin{array}{c}\text { y \% до } \\
\text { загального } \\
\text { обсягу }\end{array}$ & $\begin{array}{c}\text { млн. дол. } \\
\text { США }\end{array}$ & $\begin{array}{c}\text { y \% до } \\
\text { загального } \\
\text { обсягу }\end{array}$ & $\begin{array}{c}\text { млн. дол. } \\
\text { США }\end{array}$ & $\begin{array}{c}\text { y \% до } \\
\text { загального } \\
\text { обсягу }\end{array}$ \\
\hline Усі надходження & 6959 & 100,0 & 11111 & 100,0 & 12017 & 100,0 \\
\hline Польща & 1329 & 19,1 & 3649 & 32,8 & 3686 & 30,7 \\
\hline $\begin{array}{l}\text { Російська } \\
\text { Федерація }\end{array}$ & 1835 & 26,4 & 1091 & 9,8 & 1234 & 10,3 \\
\hline Чеська Республіка & 314 & 4,5 & 846 & 7,6 & 1113 & 9,3 \\
\hline США & 516 & 7,4 & 870 & 7,8 & 984 & 8,2 \\
\hline Великобританія & 245 & 3,5 & 394 & 3,5 & 601 & 5,0 \\
\hline Італія & 350 & 5,0 & 492 & 4,4 & 498 & 4,1 \\
\hline Німеччина & 270 & 3,9 & 426 & 3,8 & 462 & 3,8 \\
\hline Кіпр & 245 & 3,5 & 341 & 3,1 & 391 & 3,3 \\
\hline Ізраїль & 108 & 1,6 & 337 & 3,0 & 351 & 2,9 \\
\hline Греція & 191 & 2,7 & 191 & 1,7 & 195 & 1,6 \\
\hline Нідерланди & 67 & 1,0 & 123 & 1,1 & 127 & 1,1 \\
\hline Інші країни & 1489 & 21,4 & 2351 & 21,4 & 2375 & 19,7 \\
\hline
\end{tabular}

Джерело: складено автором за [7]

У 2019 році ця сума дорівнювала 22\% від суми доходів держбюджету і становила близько 8,5\% ВВП нашої країни [7].Мультиплікативний ефект на економіку України здійснює так звана формула п'яти «Т». Тобто, грошові перекази, що надходять від громадян за кордоном, сприяють розвиткові в таких сферах, як туризм, транспорт, телекомунікації, торгівля, трансферти. 
Ще однією специфічною національною проблемою останнього часу $є$ загострення конкурентної боротьби за українського студента з боку навчальних закладів зарубіжних країн, спричинене високою платою за навчання в деяких українських закладах вищої освіти. Так, за опитуванням, серед відповідей щодо приєднання України до ЄС: $(33,7 \%)$ українських респондентів приваблював вільний доступ до навчання в університетах країн-членів $Є С$ [8, с. 63].

За даними аналітичного центру CEDOS кількість українських студентів в іноземних університетах у 2017/2018 навчальному році збільшилась на $58 \%$ (порівняно з 2012/2013 навчальним роком, коли розпочалося стрімке зростання кількості українців в іноземних університетах) та становила 79 тис. осіб, із них понад 47 \% (або 37,1 тис.) навчались у Польщі. Українська студентська діаспора становить $53 \%$ від усіх іноземних студентів, що здобувають вищу освіту в Польщі, значно випереджаючи другу за розміром діаспору білоруських студентів, яка становить майже $10 \%$.

У переліку найбільш бажаних для навчання країн, як $\mathrm{i}$ раніше, залишаються Польща, Німеччина, Росія, Канада, Італія, Чехія, США, Іспанія, Австрія, Франція та Угорщина [12].

Для вирішення названих проблем державним органам влади необхідно протидіяти викликам європейської інтеграції за рахунок підвищення рівня оплати праці, створення нових робочих місць, організації освітньоінформаційної піар-кампанії щодо переваг навчання та зайнятості на Батьківщині. Посприяти цьому мають українські заклади вищої освіти за допомогою налагодження відкритого діалогу та гармонізації стосунків між закладами освіти та громадськістю.

Висновки. Підвищення мобільності людських ресурсів спричинює зміну характеру соціально-економічних відносин у сфері міжнародного туризму та міграції, що вимагає розробки нових механізмів вирішення глобальних та національних проблем. В Україні необхідно розвивати державну політику щодо трудової міграції та міжнародного туризму 3 урахуванням соціальноекономічних детермінантів для зміцнення національної безпеки, запобігання виникненню неконтрольованих міграційних процесів та ліквідації їхніх наслідків.

Стосовно виїзду студентів на навчання за кордон, заходи державної політики повинні бути спрямовані на ефективне використання здобутого інтелектуального потенціалу та інтеграцію зворотних освітніх мігрантів на українському ринку праці.

\section{Список використаних джерел}

1. Аналітична доповідь до Щорічного Послання Президента України до Верховної Ради України «Про внутрішнє та зовнішне становище України в 2018 році». Київ : НІСД, 2019. 688 с.

2. Всеукраїнська Асоціація компаній з міжнародного працевлаштування. URL: https://ampua.org/ (дата звернення: 11.04.2020). 
3. Державна служба статистики України. Офіційний сайт. URL: http://www.ukrstat.gov.ua/ (дата звернення: 11.04.2020).

4. Джеджула О.М. Особливості кредитування молодіжного туризму в Україні. Економіка. Фінанси. Менеджмент: актуальні питання науки $i$ практики. 2019. №2. С. 68-75.

5. Кубай О.Г., Страпачук М.Ю. Проблеми міграції робочої сили та шляхи їх вирішення у Вінницькій області. Актуальні питання економіки, обліку, фінансів та права: зб. тез доповідей міжнар. науково-практ. конф. у 8 ч. Полтава: ЦФЕНД, 2018. Ч. 2. С. 44-45.

6. Малиновська О.А. Міграційна політика: глобальний контекст та українські реалії : монографія. Київ : НІСД, 2018. 472 с.

7. Національний банк України. Офіційний сайт. URL: https://bank.gov.ua/statistic/macro-indicators (дата звернення: 11.04.2020).

8. Садова У. Я. Міграція в умовах трансформації регіональних ринків праці України: механізми регулювання : монографія. Львів: ДУ «Інститут регіональних досліджень імені М. І. Долішнього НАН України, 2019. 263 с.

9. Самойленко А. О. Регулювання міжнародного руху людських ресурсів України в умовах глобальної інтелектуалізації. Вісник Дніпропетровського університету. Серія : Менеджмент інновацій. 2016. Т. 24. Вип. 7. С. 250-257.

10. Сардак С. Е. Сучасна проблематика міжнародного руху людських ресурсів: міграція, туризм, транзитно-професійні переміщення, віртуальний міжнародний рух. Інвестищї: практика та досвід. 2015. № 15. С. 11-14.

11. Трудова міграція в Україні: куди та чому їдуть заробітчани. PolitekA: URL: https:// politeka.net/ua/news/612172 (дата звернення: 20.04.2020).

12. Українські студенти за кордоном: скільки та чому? Аналітичний центр CEDOS. URL: http://www.cedos.org.ua/uk/osvita (дата звернення: 21.04.2020).

13. Уніан. Інформаційне агентство. URL: https://www.unian.ua/tourism/ news/10839209 (дата звернення: 26.02.2020). 25.04.2020).

14. Центр економічної стратегіï. URL: https://ces.org.ua (дата звернення:

\section{References}

1. Analitychna dopovid do Shchorichnoho Poslannia Prezydenta Ukrainy do Verkhovnoi Rady Ukrainy «Pro vnutrishnie ta zovnishnie stanovyshche Ukrainy v 2018 rotsi» [Analytical report to the Annual Address of the President of Ukraine to the Verkhovna Rada of Ukraine "On the Internal and External Situation of Ukraine in 2018"]. K. : NISD, 2019. $688 \mathrm{~s}$.

2. Vseukrainska Asotsiatsiieiu kompanii z mizhnarodnoho pratsevlashtuvannia [All-Ukrainian Association of International Employment Companies]. URL: https://ampua.org/ (data zvernennia: 11.04.2020) [in Ukrainian].

3. Derzhavna sluzhba statystyky Ukrainy [State Statistics Service of Ukraine]. URL: http://www.ukrstat.gov.ua/ (data zvernennia: 11.04.2020) [in Ukrainian]. 
4. Dzhedzhula, O.M. (2019) Osoblyvosti kredytuvannya molodizhnoho turyzmu v Ukrayini. [Features of youth tourism lending in Ukraine]. Ekonomika. Finansy. Menedzhment: aktual'ni pytannya nauky $i$ praktyky - Economy. Finances. Management: current issues of science and practice. 2019. №2. S. 68-75.

5. Kubay, OG, Strapachuk, M.Yu. (2018). Problemy mihratsii robochoi syly ta shliakhy yikh vyrishennia u Vinnytskii oblasti [Problems of labor migration and ways to solve them in Vinnytsia region]. Aktualni pytannia ekonomiky, obliku, finansiv ta prava: zb. tez dopovidei mizhnar. naukovo-prakt. konf. u $8 \mathrm{ch}$. Poltava: TsFEND, Ch. 2. S. 44-45.

6. Malynovska, O.A. (2018). Mihratsiina polityka: hlobalnyi kontekst ta ukrainski realii [Migration policy: global context and Ukrainian realities]: monohrafiia. K. : NISD, 472 s.

7. Natsionalnyi bank Ukrainy. Ofitsiinyi sait [National Bank of Ukraine. Official site]. URL: https://bank.gov.ua/statistic/macro-indicators (data zvernennia: 11.04.2020) [in Ukrainian].

8. Sadova, U. Ya. (2019). Mihratsiia v umovakh transformatsii rehionalnykh rynkiv pratsi Ukrainy: mekhanizmy rehuliuvannia [Migration in the conditions of transformation of regional labor markets of Ukraine: mechanisms of regulation] : monohrafiia. Lviv: DU «Instytut rehionalnykh doslidzhen imeni M. I. Dolishnoho NAN Ukrainy, $263 \mathrm{~s}$.

9. Samoilenko, A. O. (2016). Rehuliuvannia mizhnarodnoho rukhu liudskykh resursiv Ukrainy $\mathrm{v}$ umovakh hlobalnoi intelektualizatsii [Regulation of the international movement of human resources of Ukraine in the conditions of global intellectualization]. Visnyk Dnipropetrovskoho universytetu. Seriia : Menedzhment innovatsii - Bulletin of Dnipropetrovsk University. Series: Innovation Management. T. 24. Vyp. 7. S. 250-257.

10. Sardak, S. E. (2015). Suchasna problematyka mizhnarodnoho rukhu liudskykh resursiv: mihratsiia, turyzm, tranzytno-profesiini peremishchennia, virtualnyi mizhnarodnyi rukh [Modern issues of the international movement of human resources: migration, tourism, transit-professional movements, virtual international movement]. Investytsii: praktyka ta dosvid - Investments: practice and experience. № 15. S. 11-14.

11. Trudova mihratsiia v Ukraini: kudy ta chomu yidut zarobitchany [Labor migration in Ukraine: where and why workers go]. PolitekA. URL: https:// politeka.net/ua/news/612172 (data zvernennia: 20.04.2020) [in Ukrainian].

12. Ukrainski studenty za kordonom: skilky ta chomu? [Ukrainian students abroad: how many and why?]. Analitychnyi tsentr CEDOS. URL: http://www.cedos.org.ua/uk/osvita (data zvernennia: 21.04.2020) [in Ukrainian].

13. Unian. Informatsiine ahentstvo. [UNIAN. News agency]. URL: https://www.unian.ua/tourism/ news/10839209 (data zvernennia: 26.02.2020) [in Ukrainian].

14. Tsentr ekonomichnoi stratehii [Center for Economic Strategy]. URL: https://ces.org.ua (data zvernennia: 25.04.2020) [in Ukrainian]. 


\title{
Відомості про автора
}

ГОЛОВНЯ Олена Михайлівна, доктор економічних наук, доцент кафедри менеджменту зовнішньоекономічної діяльності, готельно-ресторанної справи та туризму, Вінницький національний аграрний університет, (вул. Сонячна, 3, м. Вінниця, 21008, e-mail: ellens@ @eta.ua).

GOLOVNYA Elena, doctor of Economic Sciences, Associate Professor of International Management, hotel and restaurant business and tourism, Vinnytsia National Agrarian University, (21008, Vinnytsia, Soniachna str, 3, e-mail: ellens@meta.ua).

ГОЛОВНЯ Елена Михайловна, доктор экономических наук, доцент кафедры менеджмента внешнеэкономической деятельности, гостиничноресторанного дела и туризма, Винницкий национальный аграрный университет, (ул. Солнечная, 3, г. Винница, 21008, e-mail: ellens@ @eta.ua).

DOI: 10.37128/2411-4413-2020-2-4

\section{AUTOMATION OF THE FINANCIAL ANALYSIS DECISION-MAKING PROCESS ON THE INTERNET}

\author{
RUZAKOVA Olga, \\ Phd Of Economics, \\ Associate Professor, Department of Computer \\ Science \\ and Economic Cybernetics, \\ Vinnytsia National Agrarian University \\ (Vinnytsia)
} The article proposes to use modern Internet technologies for improving the accuracy, speed
and validity of financial decisions. They allow us to create a special web page where investors can
conduct an assessment of potential investment objects financial status online through an appropriate
decision support system. Research is based on the scientific works of domestic and foreign scientists
using on the assessing the financial condition of the enterprise problems, the preparation of reporting
documentation of specific enterprises, as well as taking into account the results of personal research.
A detailed analysis of theoretical, scientific and practical publications, regulatory documents for
assessing the financial condition of the enterprise, as well as relevant works on economic and
mathematical modeling is carried out. He made it possible to identify the theoretical and applied
problems in the field of study and to propose ways to solve them. The expediency of using economic
and mathematical methods for estimating the financial state of the enterprise is substantiated.
Formulated scientific provisions, conclusions and recommendations are based on the study of the
subject area, the application of methods of economic and mathematical modeling, system analysis
and methods of expert assessments. Such a system will make it possible to speed up the decision-
making process, to carryout an objective and independent expert evaluation, taking into account the
specifics of foreign financial management, to simplify the evaluation process through Internet
technologies, and to significantly reduce the cost of such service. It is proposed to apply the theory 